\title{
Measuring dry extract in dairy products: optimizing the methodology
}

\author{
Vanessa Cristina Martins ${ }^{1}$ Suzane Martins Ferreira ${ }^{1}$ Vania Silva Carvalho $^{1^{*}}$ \\ ${ }^{1}$ Instituto Federal Goiano (IF Goiano), BR 153, km 633, 75650-000, Zona Rural, Morrinhos, GO, Brasil. E-mail: vania.carvalho@ifgoiano.edu.br. \\ ${ }^{*}$ Corresponding author.
}

ABSTRACT: Dairy products are a common staple in the human diet. Moisture content is an important factor in the composition of foods, and it is a parameter used to measure product quality due to its direct influence on food storage. In this study, the moisture contents of three different products (mozzarella cheese, a creamy cheese spread, and yogurt drinks) were measured using oven drying, infrared drying, and microwave drying in order to compare the results of these three methods. Three brands of each product were used, all of which were purchased at the local supermarket in the city of Goiatuba, Goiás, Brazil. The different methods used to measure the dry extract of most of the brands analyzed did not differ significantly between each other based on a significance level of 5\% on Tukey's test. There was a significant difference between the methodologies used in the case of only one brand of each analyzed product. Microwave drying method wasreported to be a safe and reliable technique for analyzing dry extract from dairy products; it produces precise results, thus guaranteeing the quality of the analysis, and it reduces procedure time, thus optimizing the routine analytical processes performed in quality control laboratories within food processing plants. Key words: infrared drying, microwave drying, optimization, oven drying, moisture content.

Determinação de extrato seco em produtos lácteos: otimização de metodologia

RESUMO: Os produtos lácteos fazem parte da alimentação humana e o teor de umidade é uma informação importante da composição de alimentos e está entre os parâmetros da qualidade dos produtos, pois apresenta influência direta no armazenamento dos mesmos. Foram realizadas análises de umidade pela metodologia de secagem em estufa, infravermelho e micro-ondas em três produtos diferentes, sendo estes a mussarela, o queijo cremoso e a bebida láctea, com a utilização de três marcas distintas para cada produto, todas adquiridas no comércio local da cidade de Goiatuba, Goiás. Os diferentes métodos de determinação de extrato seco utilizados não diferiram significativamente entre si a um nivel de significância de $5 \%$ pelo teste de Tukey, para a maioria das marcas comerciais analisadas. Houve diferença significativa, entre as metodologias utilizadas apenas para uma marca, para cada produto analisado. A metodologia de secagem em micro-ondas é um método seguro e confiável em análises de extrato seco em derivados lácteos, com resultados precisos garantindo a qualidade nos processos analíticos, como também a redução do tempo de análise garantindo a otimização desse processo nas análises de rotina em laboratórios de controle de qualidade das indústrias alimenticias.

Palavras-chave: otimização, teor de umidade secagem em estufa, infravermelho, micro-ondas.

\section{INTRODUCTION}

In the many sectors that make up the food industry, dairy production is of particular importance: in 2009 , it ranked fourth in terms of value in Brazil (after meat products, coffee, tea, and cereal products, and sugars); and is therefore, a major player in Brazilian agribusiness (SOUZA, 2014).

Food processing plants seek to meet the current market's quality and price demands; to do so, both high-quality raw materials and effective cost management strategies for the production process are necessary (CORREIA et al., 2012). Various physical, chemical, microbiological, and sensorial analyses are also required to reliably produce quality products. These analyses are able to ensure that products comply with the standards defined by the current legislation. In the case of dairy products, one analysis consists of the measurement of dry extract.

Moisture content is an important factor in the composition of foods, and it is a routinely analyzed parameter. It can serve as an indicator of product quality, since it directly influences product storage (AMOEDO \& MURADIAN, 2002). According to MENDONÇA et al. (2007), the different methods used to measure moisture content all consist of 
removing water from foods through heating. In these processes, the moisture content is calculated as the difference between initial and final sample weights. Oven drying is considered the standard method for measuring moisture content. In the case of oven drying, moisture content is most commonly defined as the amount of moisture lost via desiccation at a temperature of $105 \pm 3^{\circ} \mathrm{C}$ after 24 hours.

This method is based on the quantification of weight due to the loss of water by evaporation, which is determined by direct desiccation in an oven at approximately $105^{\circ} \mathrm{C}$ (ZENEBON et al., 2008). This method offers the advantages of being easy to carry out and capable of processing a large number of samples at once; it is largely for these reasons that is so commonly employed in laboratories. However, it is a time-consuming procedure in laboratory routines, as well as for food processing plants that require rapid results (ILELEJI et al., 2010).

PITARELO et al. (2012) presented an alternative to the oven-drying method: infrared drying, in which mass is measured after a short infrared radiation drying process. This drying process may be carried out until a constant weight, a specific temperature, or a specific time is reached. The time required to obtain results using this methodology ranges from 6 to 8 minutes, depending on the original texture and moisture content of the material being analyzed.

Microwave radiation can also measure moisture loss by desiccation and is an additional alternative to the conventional method. It optimizes traditional oven drying allowing moisture content to be calculated more quickly while producing results that are consistent with those of oven drying. One study reported that microwave radiation analysis reduces procedure times by a factor as high as 15 , and this same study obtained measurements in approximately 4 minutes (BIZZI et al., 2011).

But drying can not be done randomly, as the industry aims to; and therefore, it is appropriate to use a method that aims reducing time to obtain elaboration of laboratory technical reports (MOURA \& SILVA, 2017). Several authors report that industries need time optimization to obtain their products as well as to carry out quality control analyzes (DOMENICO et al., 2017; RAPONI et al., 2017; OMOLOLA et al., 2015).

In light of these factors, this study sought to determine the ideal parameters for optimizing moisture content analyses performed on dairy products using industrial microwave equipment relative to infrared drying and to traditional oven drying.

\section{MATERIALS AND METHODS}

The three different products used in this study were mozzarella cheese, creamy cheese spread (a common Brazilian food product similar to American cream cheese), and yogurt drinks. The analyses involved three brands of each product, which were purchased from the local supermarket in the city of Goiatuba, Goiás, Brazil. According to PENNA et al. (2001), Brazilian yogurt drinks are a type of fermented milk that has been marketed as a "yogurt substitute". They may be made from milk, reconstituted milk, or milk products (including whey) - products which may also be reconstituted. According to the definition from Brazilian Regulatory Instrument No. 16 from August 23, 2005, a yogurt drink is the result of the mixture of milk (in natura, pasteurized, sterilized, ultra-pasteurized, reconstituted, concentrated, in powder form, whole-fat, skim, or nonfat) and whey (liquid, concentrated, or in powder form), and it may include food products or substances such as vegetable shortening, fermented milk, fermented milk products, and other dairy products.

Products and controls were kept at appropriate temperatures at the plant until the analyses: the mozzarella was frozen, the yogurt drinks were stored at room temperature, and the creamy cheese spreads were refrigerated at $6^{\circ} \mathrm{C}$. The entire study was carried out in the dairylab of a food processing plant located in southern Goiás State, where moisture content could be analyzed using the three different methods considered herein: the traditional oven-drying method, infrared radiation, and microwave drying.

Three tests were performed on each of the three brands of each product in order to obtain the best results possible for the parameters being used to determine which method is most adequate for measuring dry extract in dairy products.

The first products tested were the three brands of mozzarella cheese (M1, M2, and M3), followed by the creamy cheese spread samples $(\mathrm{C} 1$, $\mathrm{C} 2$, and $\mathrm{C} 3$ ), and, finally, by the yogurt drink brands (Y1, Y2, and Y3). Mozzarella blocks were shredded using a manual stainless-steel cheese grater in order to increase surface area and, in doing so, better remove moisture from the samples during the drying process. Neither the creamy cheese spread samples nor the yogurt drink samples required any preparation prior to analysis.

Dry extract analyses using the conventional oven-drying method were performed according to the methods proposed by the Association of Official 
Analytical Chemists (2016) and the procedure specified by the Adolfo Lutz Institute (ZENEBON et al., 2008). Because this is a reliable and precise method, and by this method be used officially, it was also a parameter for the other two methods. Equipment used was the Marconi-MA033 drying oven.

The second drying method tested herein was infrared radiation on a Gehaka (model IV 2000) moisture determination balance. All of the tests were performed following the manufacturers' instructions in the instruction manuals. Food was placed on the balance, and when the balance reached $110^{\circ} \mathrm{C}$, it emitted a sound to announce the end of the analysis, at which point the result was displayed on the digital screen.

Drying via electromagnetic radiation in a microwave was also performed to determine the optimal method for measuring dry extract from dairy products. The equipment used was the CEM Labwave 9000 Moisture/Solids Microwave Analyzer ${ }^{\mathrm{TM}}$ (model Smart Turbo). In the case of the yogurt drinks, the power used was $80 \mathrm{~W}$, while in the case of the creamy cheese spreads and mozzarella cheeses, the power used was $95 \mathrm{~W}$. The energy levels chosen were based on the data obtained from preliminary studies using the Labwave $9000^{\mathrm{TM}}$. The time required to perform the analysis was established by preliminary tests where the final moisture content was based on that obtained in the conventional drying method. The procedure was performed according to the manufacturer's instructions, as specified in the manual (CEM, 1995).

In all methodologies, the time required for the samples to reach constant weight was observed in order to obtain a comparison of the time in relation to the methods employed. To obtain the time data a stopwatch was used (VOLLO - VL1809).
Once the analyses were complete, the data were compiled and analyzed. Analysis of variance (ANOVA) was applied to determine any differences between the means. Tukey's test was also employed to determine ranges between means. The mean and standard deviation were calculated of all the times used for each methodology in each sample. These tests aided in the determination of which methods are optimal for measuring dry extracts from these dairy products. The computer program used was Sisvar, version 5.6.

\section{RESULTS AND DISCUSSION}

Table 1 shows the results in triplicate of the three mozzarella brands (M1, M2, and M3), of creamy cheese $(\mathrm{C} 1, \mathrm{C} 2$, and $\mathrm{C} 3)$ and yogurt drinks (Y1, Y2, and $\mathrm{Y} 3$ ) using different drying methods.

As table 1 shows, results of the application of the microwave drying method to the M1 brand differed significantly from those produced by the other drying methods, according to Tukey's test. Meanwhile, results for the M2 and M3 brands did not differ significantly, regardless of the method.

According to FURTADO (1997), Brazilian mozzarella cheese brands are very inconsistent in their physical and chemical compositions as a result of substantial variations in production methods. These variations are themselves due to the lack of legal norms or standards for cheese production in the country. These authors reported that Brazilian mozzarella cheese composition ranges from $43 \%$ to $46 \%$ moisture and from $40 \%$ to $45 \%$ fat in the dry extract.

Moisture content reported in the mozzarella cheese brands tested (Table 1) herein were within the

Table 1 - Analyses of the dry extracts from the three brands of mozzarella cheese (M1, M2, and M3), of creamy cheese (C1, C2, and C3) and yogurt drinks (Y1, Y2, and Y3) using different drying methods (mean \pm standard deviation; $n=3$ ).

\begin{tabular}{|c|c|c|c|}
\hline & Oven drying & Infrared drying & Microwave drying \\
\hline M1 & $57.93 \pm 0.04^{\mathrm{a}}$ & $57.70 \pm 0.08^{\mathrm{a}}$ & $57.33 \pm 0.04^{\mathrm{b}}$ \\
\hline M2 & $54.96 \pm 0.04^{\mathrm{a}}$ & $54.90 \pm 0.08^{\mathrm{a}}$ & $54.80 \pm 0.08^{\mathrm{a}}$ \\
\hline M3 & $57.27 \pm 0.04^{\mathrm{a}}$ & $57.17 \pm 0.18^{\mathrm{a}}$ & $57.33 \pm 0.13^{\mathrm{a}}$ \\
\hline $\mathrm{C} 1$ & $34.74 \pm 0.12^{\mathrm{a}}$ & $34.43 \pm 0.09^{\mathrm{a}, \mathrm{b}}$ & $34.23 \pm 0.12^{b}$ \\
\hline $\mathrm{C} 2$ & $34.26 \pm 0.28^{\mathrm{a}}$ & $34.33 \pm 0.17^{\mathrm{a}}$ & $34.13 \pm 0.12^{\mathrm{a}}$ \\
\hline $\mathrm{C} 3$ & $36.18 \pm 0.17^{\mathrm{a}}$ & $36.13 \pm 0.09^{\mathrm{a}}$ & $36.23 \pm 0.17^{\mathrm{a}}$ \\
\hline Y1 & $19.55 \pm 0.27^{\mathrm{a}}$ & $19.77 \pm 0.31^{\mathrm{a}, \mathrm{b}}$ & $20.37 \pm 0.13^{\mathrm{b}}$ \\
\hline Y2 & $18.67 \pm 0.19^{\mathrm{a}}$ & $18.47 \pm 0.13^{\mathrm{a}}$ & $18.50 \pm 0.08^{\mathrm{a}}$ \\
\hline Y3 & $19.93 \pm 0.06^{\mathrm{a}}$ & $20.10 \pm 0.08^{\mathrm{a}}$ & $20.23 \pm 0.17^{\mathrm{a}}$ \\
\hline
\end{tabular}

Identical letters in a single lines reflect a lack of significant difference as per Tukey's test $(\mathrm{P}<0.05)$. 
standard range required by the Ministério da Agricultura, Pecuária e Abastecimento do Brasil (MAPA), as outlined in Regulatory Instrument No. 364 from September 4, 1997, which states that the moisture content $(\mathrm{g} / 100 \mathrm{~g})$ may be, at most, 60.0g (BRASIL, 2011).

Results showed that the results produced by the oven-drying and infrared methods did not differ significantly between each other according to Tukey's test, nor did the results of the microwave and infrared methods. Results of the $\mathrm{C} 2$ and $\mathrm{C} 3$ brands did not differ significantly when any of the drying methods were applied. However, results for the C1 brand differed significantly between the oven-drying method and the microwave drying method.

Current Brazilian legislation does not set specific standards regarding the identity or quality of creamy cheese spread. However, ALVES et al. (2008) reported total dry extract measurements in Americanstyle cream cheeses to range from, $33.44 \pm 0.21 \%$ to $39.46 \pm 0.29 \%$, results which were similar to those of Brazilian creamy cheese spreads. Because there are no standards regulating American-style cream cheese in Brazil, its formulation; is therefore, based on the Codex Alimentarius (2012), which establishes standards for cream cheese production and sale a which serve as a parameter for the product's production.

Results of these yogurt drink analyses show that the results produced by the oven-drying and infrared methods did not differ significantly between each other according to Tukey's test, nor did the results produced by the microwave and infrared methods. Results of the Y2 and Y3 brands did not differ significantly when any of the drying methods were applied.

As PENNA et al. (2001) mentioned in their description of Brazilian yogurt drinks, standard proportions of milk and whey have not been clearly defined for processing, which results in different moisture contents in the products on the market. In the Brazilian government's definition of yogurt drinks and their processing standards, the milk base must represent at least $51 \%$ mass $/$ mass $(\mathrm{m} / \mathrm{m})$ of the total ingredients; a specific standard for moisture content; however, is not included in this definition (BRASIL, 2011).
The addition of whey results in a product with lower dry extract content. Measurements obtained in this study after the use of the three different drying methods (Table 1) were close to those obtained by PENNA et al. (2001), who reported moisture contents ranging from $19.01 \%$ to $21.71 \%$; they were also similar to the results obtained by CUNHA et al. (2008), who reported moisture contents ranging from $18.09 \%$ to $19.44 \%$.

Despite the differences reported in samples $\mathrm{M} 1, \mathrm{C} 1$ and $\mathrm{Y} 1$ for the microwave drying method, all results are in compliance with the legislation in the country. This difference can be reduced or eliminated by adjusting the residence time of the samples in the industrial microwave equipment. As the products are industrialized and purchased locally, brand factors, formulation and number of series may be variables that determined a difference between microwave drying and other methods.

Food processing plants face the challenge of reducing routine laboratory analysis times in order to lower costs for materials and labor. These processes can be optimized through the use of reliable, modern, and practical equipment. Processing parameters that can be optimized include temperature, relative moisture, air flow during the drying process, electromagnetic waves, infrared radiation, power and intensity, pressure, sample size, retention time, and many other factors associated with the various drying methods available (DARK et al., 2014). All three drying processes tested herein exhibited favorable results in terms of precision and accuracy when used to analyze mozzarella cheese, creamy cheese spreads, and yogurt drinks. All three methods can; therefore, be safely utilized by food processing plants.

Among the parameters considered in the comparison between the three drying methods, the time required for analysis produced the greatest potential in terms of optimization. Table 2 shows the times required for analysis, as well as the temperature, power, and quantity of products (solids and liquids) in the analyses of the three methods used to measure dry extract in mozzarella cheese, creamy cheese spreads, and yogurt drinks.

Table 2 - Data on temperature, equipment power, and sample size required by the three dry extract measurement methods.

\begin{tabular}{lccccc}
\hline & Time $(\mathrm{Min})$ & Temperature $\left({ }^{\circ} \mathrm{C}\right)$ & Power $(\%)$ & Solid Mass $(\mathrm{g})$ & Liquid Mass $(\mathrm{ml})$ \\
\hline Oven drying & $480 \pm 30$ & 105 & - & 3.0 & 5.0 \\
Infrared drying & $6 \pm 2$ & 110 & - & 1.0 & 1.2 \\
Microwave drying & $4 \pm 1$ & - & $80-95$ & 1.5 & 1.5 \\
\hline
\end{tabular}


The oven-drying method required the most time for analysis: approximately 8.5 hours at a temperature of $105^{\circ} \mathrm{C} \pm 5$. Though the method produces precise results, it is time consuming; and therefore, often unfeasible in processing plants that require rapid results on laboratory analyses of industrial processes.

The infrared analyses were performed at $110^{\circ} \mathrm{C}$, and the time required for results to be presented on the balance ranged from 6 to 8 minutes. In each infrared analysis, $1.0 \mathrm{~g}$ of mozzarella, $1.0 \mathrm{~g}$ of creamy cheese spread, or $1.2 \mathrm{ml}$ of yogurt drink was used.

According to KANTRONG et al. (2014), the infrared drying method stands out relying on easy-to-use automated equipment that is energy efficient and which produces high-quality results. Time required for analysis using this method is much lower than the time required for traditional oven drying; however, RASCHEN et al. (2014) note that infrared drying exhibits a disadvantage in the fact that only one sample can be dried at a time, a factor which significantly increases testing time. Another factor associated with issue is that is more difficult to maintain high temperatures when samples are introduced one at a time; this process may; therefore, result in less-than-perfect test-retest reliability. Furthermore, infrared drying may burn samples as a result of overheating, and there may be variations in the amount of electric energy during the measurements. All of these factors may compromise the precision of the moisture determination balance and, in turn, the results.

Even so, the method is commonly used in quality control laboratories, and results are, in fact, reliable when the necessary attention is given to calibrations, cleaning, handling, and the electricity source. The professional must also be properly trained to utilize and perform maintenance on the equipment.

In the case of the microwave analyses, $1.5 \mathrm{~g}$ or $1.5 \mathrm{ml}$ of each product were used in each test. The power was set at $80 \%$ in the yogurt drink analyses, and it was set at $95 \%$ in the case of the mozzarella cheese and creamy cheese spread analyses. The microwave drying method required the least amount of time for analysis when compared to the other methods: the time required was approximately 102 times less than the time required for traditional oven drying.

The CEM Labwave 9000 Moisture/Solids Microwave Analyzer essentially consists of three components: a microwave drying system, an integrated analytical balance, and a small computer. The device releases approximately $630 \mathrm{~W}$ of microwave energy at a frequency of $2450 \mathrm{MHz}$ when set to $100 \%$ power.
The amount of energy is programmed before the analysis by establishing the percentage of energy to be applied in each second of the operation while the magnetron continues to operate at $100 \%$ power. Thus, at $50 \%$ power, for example, the instrument releases $630 \mathrm{~W}$ of power per half-second and deactivates the microwaves for the next half-second.

In their research, RASCHEN et al. (2014) used $697 \mathrm{~W}$, which corresponded to $77.4 \%$ power and which produced a map of the radiation within the oven. Waves were heterogeneous, which aided in the drying of the samples. Microwave drying method produced a level of accuracy similar to that of conventional oven drying. They reported that the microwave drying method offers a variety of advantages relative to the other methods, and, in their study, it reduced procedure times by a factor of 29 .

These differences in procedure times reflect the advantages of the microwave drying method over the infrared drying method: microwave drying produces results in 4 minutes; and therefore, optimizes quality control processes in laboratory analyses. This reduced time also results in energy savings for food processing plants.

BUSKE et al. (2014) and SHI et al. (2013) also reported that this method did not differ significantly from the standard oven-drying method and declared it to be a reliable and easy-to-use option that can significantly reduce drying time while improving product quality. As these studies and the current study have shown, microwave drying is quick and simple, and it produces satisfactory qualitative and quantitative results. In addition to the aforementioned advantages, it also offers advantages in terms of hygiene. Microwave drying; is therefore, a promising technique for measuring dry extract from foods. This technique has also been studied in recent years as a potential drying method for biological products, and high-quality results have been produced this far (KANTRONG et al., 2014).

SHI et al. (2013) argued that the most advantageous aspects of microwave drying are that quality control agents can evaluate whether the results of industrial processes are stable and can also determine whether company standards are reached. The most common results of interest in the processed food industry are decreases in waste, increases in yield, shorter operating times, the need for fewer raw materials, increased utilization of resources, reduced variability, and products that are closer to a given measurement or target, all of which improve the chances of increased financial gains. Thus, the optimization of any drying process must ensure that the procedure is 
short but able to produce a high-quality product on an industrial scale (DARK et al., 2014).

Results presented in this research came from industrial equipment for all methods used (conventional oven-drying, infrared radiation and electromagnetic radiation in a microwave), while the great majority of the literature obtains results of domestic equipment, especially when the drying is performed in microwave. Therefore, the results obtained, besides presenting great precision for the analyzed samples, reduces the time of accomplishment of the same ones.

The data obtained herein are promising for the processed food industry, which seeks to optimize production methods, reduce the times required for analyses, and lower costs while maintaining accurate results. However, the industry must still make a costbenefit relation for the acquisition of the industrial microwave, considering that it has an estimated value.

From the economic point of view, it is known that the industrial microwave has a cost higher than the infrared equipment. However, when it comes to reducing analytical time in quality control laboratories in the food industry, the value of the equipment becomes less questioned. Because an industry that works 24 hours a day, it must be extremely efficient and fast in releasing technical reports of finished products. Therefore, the optimization of time in these analyzes is fundamental for the production process to be linear to the quality control of the food industries.

\section{CONCLUSION}

The different methods used to measure the dry extract of most of the brands analyzed did not differ significantly between each other based on a significance level of $5 \%$ on Tukey's test. There was a significant difference between the methodologies used in the case of only one brand of each analyzed product.

This study showed that the microwave drying method is secure and reliable for analyzing dry extract from dairy products; it produces precise results that can guarantee the quality of analytical processes. The study also revealed that the time required to measure dry extract was much lower when this method was used; microwave drying was approximately 102 times faster than traditional oven drying. Microwave drying can; therefore, optimize drying methods in routine laboratory analyses performed as part of quality control processes in food processing plants.

\section{ACKNOWLEDGEMENTS}

The authors thank the Instituto Federal Goiano (IF Goiano) for its support in the development of the paper and the publication of the article.

\section{CONFLICTS OF INTEREST}

The authors declare no conflict of interest. The founding sponsors had no role in the design of the study; in the collection, analyses, or interpretation of data; in the writing of the manuscript, and in the decision to publish the results.

\section{REFERENCES}

ALVES, L. L.; et al. Avaliação sensorial de cream chesses potencialmente simbióticos utilizando a metodologia de superficie de resposta. Alimentos e Nutrição, v.19, n.4, p. 409-416, 2008. Available from: <http://www. scopus.com/inward/record.url?eid=2-s2.0-84872276788\&partnerID $=4$ 0\&md5=1d927d2737e11d3363d525971301bf5e>. Accessed: Nov. 23, 2017. doi: 10.1111/j.1471-0307.2012.00880.x.

AMOEDO, L. H. G.; MURADIAN, L. B. A. Comparação de metodologias para a determinação de umidade em geleia real. Química Nova, v. 25, p. 676-679, 2002. Available from: $<$ http://www. scielo.br/scielo.php?pid=S0100-40422002000400024\&script $=$ sci abstract\&tlng=pt>. Accessed: Nov. 23, 2017. doi: 10.1590/S010040422002000400024.

ASSOCIATION OF OFFICIAL ANALYTICAL CHEMISTS (AOAC). Official methods of analysis. $20^{\mathrm{a}}$ ed., $4^{\mathrm{a}}$ rev. Pharmabooks: Published by AOAC International, v. 2, cap. 32, p.1-43, 2016.

BIZZI, C. A.; et al.. A fast microwave-assisted procedure for loss on drying determination in saccharides. Journal Brazilian Chemistry Society, v.22, p.377-381, 2011. Available from: <http://www.scielo. $\mathrm{br} / \mathrm{scielo} . \mathrm{php}$ ? pid $=\mathrm{S} 0103-50532011000200026 \& \mathrm{script}=\mathrm{sci}$ abstract\&tlng=pt $>$. Accessed: Nov. 23, 2017. doi: 10.1590/S010350532011000200026 .

BRASIL. Instrução Normativa $n^{\circ} 16$, de 23 de agosto de 2005. Ministério da agricultura, pecuária e abastecimento. Nova Legislação comentada de produtos lácteos. 3. ed. rev. Ampl. e comentada. São Paulo: Setembro, 2011.

BUSKE T. C.; et al. Determination of soil moisture by different heating sources. Irriga, v. 19, n. 2, p. 315-324, 2014. Available from: <https:// www.researchgate.net/publication/280768121_DETERMINACAO_ DA_UMIDADE_DO_SOLO_POR_DIFERENTES_FONTES_DE_AQUECIMENTO $>$. Accessed: Nov. 24, 2017. doi: 10.15809 .

CEM Manual de Operações: Analisador de umidade Voláteis/ Sólidos. Versão 9000 ${ }^{\mathrm{TM}}$ [S.I.]: CEM Corporation, 1995.

CODEX ALIMENTARIUS. CODEX STAN 275-1973, [S.I.] 2012. Washington, p. 1-7 Available from: <file://C:/Users/Usuario/ Downloads/CXS_275e\%20(1).pdf>. Accessed: May 17, 2017.

CORREIA, L. F. M; et al. Costs of milk collection and evaluation of officiency in the dairy industry. Revista do Instituto de Laticínios Cândido Tostes, v. 67; n. 388, p. 15-24, 2012. Available from: $<$ https://www.revistadoilct.com.br/rilct/article/view/261>. Accessed: Nov. 24, 2017. doi: 10.5935/2238-6416.20120060. 
CUNHA, T. M. et al. Avaliação físico-química, microbiológica e reológica de bebida láctea e leite fermentado adicionados de probióticos. Semina: Ciências Agrárias, v. 29, n. 1, p. 103-116, mar. 2008. Available from: $<$ https://www.researchgate.net/publication/276227785 Avaliacao fisico-quimica_microbiologica_e_reologica_de_bebida_lactea_e_leite fermentado_adicionados_de_probioticos $>$. Accessed: Nov. 24, 2017. doi: $10.5433 / 1679-0359$.

DARK, M. et al. Optimization of microwave-vacuum drying of pomegranate arils. Food Measure, v. 8, p. 398-411, 2014.Available from: $<$ http://www.tandfonline.com/doi/abs/10.1080/07373930701370407>. Accessed: Nov. 24, 2017. doi: 10.1080/07373930701370407.

DOMENICO, C. N. B. D. et al. O uso de redes neurais artificiais na otimização do processo de secagem convectiva de alimentos e redução do consumo energético. Ágora Revista Eletrônica, n. 24, p. 90-108, 2017. Available from: <http://agora.ceedo.com.br/ojs/ index.php/AGORA_Revista_Eletronica/article/view/289/246>. Accessed: Apr . 23, 2018.

FURTADO, M. M. Manual prático da mussarela (pizza cheese). Campinas: Master Graf, 1997. 70 p.

ILELEJI, K. E. et al. Comparison of standard moisture loss-ondrying methods for the determination of moisture content of corn distillers dried grains with solubles. Journal of AOAC International, v. 93, n 3, p. 825-832, 2010. Available from: <https:/www.ncbi.nlm.nih.gov/ pmc/articles/PMC4213707/>. Accessed: Nov. 24, 2017. doi: 10.5713.

KANTRONG, H.; et al. Drying characteristics and quality of shiitake mushroom undergoing microwave-vacuum drying and microwavevacuum combined with infrared drying. Journal of Food Science and Technological, v. 51, n. 12, p. $3594-3608,2014$. Available from: $<$ https://www.ncbi.nlm.nih.gov/pubmed/25477627>. Accessed: Nov. 24, 2017. doi: 10.1007/s13197-012-0888-4.

MENDONÇA, J. C. F; et al. A comparative evaluation of methodologies for water content determination in green coffee. LWT - Food Science and Technology, v.40, n.7, p.1300-1303, 2007. Available from: <https:// www.researchgate.net/publication/229300751_A_comparative_ evaluation_of_methodologies_for_water_content_determination in_green_coffee $>$. Accessed: Nov. 24, 2017. doi: 10.1016/j. lwt.2006.08.013.
MOURA, H. N. A.; SILVA, D. C. Avaliação do planejamento experimental no processo de secagem do inhame (discorea spp.). Revista de Iniciação Científica, v. 4, n. 6, 2017. Available from: <http://itp.ifsp. edu.br/ojs/index.php/IC/article/view/1030/782>. Accessed: Apr. 23, 2018.

OMOLOLA, A. O.; et al. Optimization of microwave drying conditions of two banana varieties using response surface methodology. Food Science and Technology, v. 35, n. 8, p. 438-444, 2015. doi: 10.1590/1678-457X.6700

PENNA,A. L. B.; et al. Relation between quality and rheological properties of lactic beverages. Journal of Food Engineering, v. 49, n. 1, p. 7-13, 2001.Available from: $<$ https://repositorio.unesp.br/handle/11449/32520>. Accessed: Nov. 24, 2017. doi: 10.1016/S0260-8774(00)00179-5.

PITARELO, A. P.; et al. Efeito do teor de umidade sobre o pré-tratamento a vapor e a hidrólise enzimática do bagaço de cana-de-açúcar. Química Nova, v. 35, n. 8, p. 1502-1509, 2012. Available from: $<$ http://www.scielo.br/scielo. php?pid=S0100-40422012000800003\&script=sci_abstract\&tlng=p $>$. Accessed: Nov. 24, 2017. doi: 10.1590/S0100-40422012000800003.

RAPONI, F.; et al. Monitoring and Optimization of the Process of Drying Fruits and Vegetables Using Computer Vision: A Review. Sustainability, v. 9, p. 2009-2016, 2017. doi: 10.3390/su9112009.

RASCHEN, M. R.; et al. Determinação do teor de umidade em grãos empregando radiação micro-ondas. Ciência Rural, v. 44, n. 5, p. 925 930, 2014. Available from: $<$ http://www.scielo.br/scielo.php?script=sci arttext\&pid=S0103-84782014000500026>. Accessed: Nov. 24, 2017. doi: 10.1590/S0103-84782014000500026.

SHI, Q.; et al. Optimization of combined heat pump and microwave Drying of yacon (smallanthus sonchifolius) using response surface methodology. Jounal of Food Processing and Preservation, v. 38, n. 5, p. 20902098, 2013. Available from: <http://onlinelibrary.wiley.com/doi/10.1111/ jfpp.12189/full>. Accessed: Nov. 24, 2017. doi: 10.1111/jfpp.12189.

SOUZA, J. J. Notas sobre a Indústria se Laticínios no Brasil e seu processo de formação perante a economia mundial. CaderNAU, v. 6, n. 1, p. 29-39, 2014.

ZENEBON, O. et al. Métodos Físico-químicos para análise de alimentos. São Paulo: Instituto Adolf Lutz, 2008. 1020 p. 